\title{
Half-castration is a newly effective method for increasing yield and tenderness of male cattle meat
}

\author{
Van-Ba Hoa ${ }^{1}$, Dong-Heon Song ${ }^{1}$, Kuk-Hwan Seol ${ }^{1}$, Sun-Moon Kang ${ }^{1}$, \\ Hyun-Wook Kim ${ }^{1}$, Sun-Sik Jang ${ }^{2}$, and Soo-Hyun Cho ${ }^{1 \text {,* }}$
}

\section{* Corresponding Author: Soo-Hyun Cho Tel: +82-63-238-7351, \\ E-mail: shcho0915@korea.kr}

${ }^{1}$ Animal Products Utilization Division, National Institute of Animal Science, RDA, Wanju 55365 , Korea

${ }^{2}$ Hanwoo Research Institute, National Institute of Animal Science, Pyeongchang, 25340, Korea

ORCID

Van-Ba Hoa

https://orcid.org/0000-0001-8725-1504 Dong-Heon Song

https://orcid.org/0000-0002-4670-3321

Kuk-Hwan Seol

https://orcid.org/0000-0002-0907-882X Sun-Moon Kang

https://orcid.org/0000-0003-3947-4337

Hyun-Wook Kim

https://orcid.org/0000-0002-2979-345X

Sun-Sik Jang

https://orcid.org/0000-0002-8121-4697

Soo-Hyun Cho

https://orcid.org/0000-0002-8073-8771

Submitted Dec 7, 2021; Revised Dec 28, 2021; Accepted Jan 18, 2022
Objective: For improving meat quality especially tenderness, male cattle are usually castrated to removes both the testicles. This study was conducted to evaluate the effect castration method (half- and complete-castration) on meat yield and quality characteristics of Hanwoo male cattle.

Methods: Thirty-two similar age (5.9 months) Hanwoo male calves were divided into: half-castration (HC) and complete-castration (CC) groups ( $\mathrm{n}=16$ per group). At 7 months of age, all the animals were castrated in which the $\mathrm{HC}$ calves had only one testicle surgically removed while, the CC calves had both testicles surgically removed. The castrated animals were reared under identical conditions until 25 months of age. After slaughter, the carcasses were evaluated for carcass traits and meat yield of primal cuts. For examination of the castration effect on meat quality, L. lumborum and semimembranosus muscles were used. The meat samples were analyzed for chemical composition, color, $\mathrm{pH}$, shear force and water holding capacity, fatty acids, metabolites and volatile aroma compounds.

Results: The HC group showed higher meat yields of all primal cuts $(\mathrm{p}<0.05)$. As a result, the total meat yield was higher by approximately $44 \mathrm{~kg}$ in the HC group $(303.32 \mathrm{~kg}$, corresponding to $67.88 \%$ ) compared to the CC group $(259.30 \mathrm{~kg}$, corresponding to $62.11 \%)$ (p< 0.05). In terms of meat quality, the $\mathrm{HC}$ resulted in two times greater fat content in both muscles examined compared to intact males. More importantly, the shear force values did not differ between HC and CC groups for L. lumborum muscles ( $\mathrm{p}>0.05)$. The meat from $\mathrm{HC}$ animals exhibited higher amount of free amino acids associated with sweetness $(\mathrm{p}<$ 0.05). Furthermore, the castration method only exhibited a negligible effect on metabolites and volatile aroma compounds in the cooked meat.

Conclusion: Half-castration emerged as an alternative practice to be used for increasing the yield and tenderness of male cattle meat.

Keywords: Castration; Half-castration; Meat Quality; Meat Yield; Tenderness

\section{INTRODUCTION}

Meeting the quality and quantity demands for consumers is of vital importance for the beef industry. Despite the Corona virus pandemic disruptions, consumer demand for beef still remained strong in 2020, with per capita consumption of about $26.53 \mathrm{~kg}$ [1]. However, not only did consumers consume more beef, they also requested higher-quality beef [2] due to the changes in consumer preferences and quality perceptions [3]. Consumer studies have shown that the preference and purchasing decision for beef rely on a number of factors such as lean color, marbling (intramuscular fat [IMF]) degree and tenderness etc. which also vary among the markets [4]. In general, almost all consumers consider meat tenderness as the important qualitative trait that determines acceptability, satisfaction and willingnessto-pay premium prices [5]. In some markets, beside the tenderness, the marbling (IMF) 
degree is the most important factor determining the overall eating quality, purchasing decision and price of beef [4]. Because, the marbling level has been found to be the main driver of beef eating quality as it positively affects tenderness, juiciness, flavor and overall liking [6]. Contrastingly, in some countries, a significant ratio of consumers generally do not prefer highly-marbled beef due to the health concerns [7]. In this context, producing tenderness-guaranteed beef with different IMF levels (e.g., low, moderate and medium) is necessary to meet the demands of these market segmentations.

Pre- or post-pubertal castration of male cattle is a common management practice in beef production systems. Castration is a process that removes or inactivates the testicles of a bull by using either surgical or stopping blood flow to the testes and immunocastration methods [8]. The castration has been reported to produce a lot of advantages such as decreased aggressiveness and sexual behavior, enhanced on-farm safety and stopped male hormone production etc. [8,9]. However, the castration also has some major disadvantages such as slower growth rate and lesser feed conversion efficiency compared to non-castration (intact males) [10,11]. This is due to the reduced concentrations of serum growth-enhancing sexual hormones such as testosterone in the castrated males (steers) since it is mainly responsible for muscular tissue development $[9,12]$. Practically, the castration has been proposed as a means of enhancing meat quality especially tenderness because castration of bulls increases carcass back-fat thickness [13] and IMF content [13,14]. In countries such as Korea, for highly marbled beef meat production, approximately $98 \%$ of male calves are subjected to surgical castration to remove both testicles [15]. As above-mentioned, the growthenhancing sexual hormones (e.g., testosterone) strongly affects growth rate and metabolisms such as myonucleic formation and protein synthesis [16], and daily weight gain [12]. Since the testosterone is mainly produced by two testes, maintaining a certain level by removing only one testicle may have a potential to improve the IMF accumulation and meat quality (tenderness) while, still supporting muscular protein synthesis.

In this study, two different surgical castration methods: i) complete castration (CC, completely removed both testicles), and ii) half-castration (HC, removed only one testicle) were applied to investigate their effects on carcass traits, meat yield and quality characteristics of Hanwoo cattle.

\section{MATERIALS AND METHODS}

\section{Animal care}

The animal and protocols used in the present study were reviewed and approved by the Institutional Animal Care and Use Committee (IACUC) at National Institute of Animal Science (Approval No. NIAS 20001992).

\section{Animals and samples preparation}

In the present investigation, the trials were carried out on 32 similar age (5.9 months) Hanwoo male calves. The calves were randomly divided into i) HC (initial body weight: 147.53 $\mathrm{kg}$ ) and ii) CC (initial body weight: $149.33 \mathrm{~kg}$ ) groups ( $=$ 16 per group). At 7 months of age, all the animals were castrated in which the $\mathrm{HC}$ calves had only one testicle surgically removed while, the $\mathrm{CC}$ calves had both testicles surgically removed. Following the castration, the castrated animals were reared in separated pens (4 calves/pen with an area of $5 \times 10 \mathrm{~m}^{2}$ ) under the identical environmental condition and fed the same diet. Particularly, during the growing period (6 to 14 months of age), approximately 3.0 to $7.5 \mathrm{~kg}$ of formula feed and 3 to $4.0 \mathrm{~kg}$ of Italian ryegrass per animal were provided. At the fattening period ( 15 to 25 months of age), approximately 8 to $9.5 \mathrm{~kg}$ of formula feed and 1 to $3.0 \mathrm{~kg}$ of rice straw per animal were provided. The details on ingredients and chemical composition of experimental diets are described in our previous study [17]. At the end of fattening period, the animals were shipped to a practical plant (Jeonju, Korea) where they were slaughtered following the commercial procedure, and the carcass sides were chilled at $2{ }^{\circ} \mathrm{C}$ in a chilling room. Twenty-four hours after slaughter, the carcasses were evaluated for carcass traits (e.g., weight and dressing), and then they were fabricated into primal cuts that were deboned and trimmed of external fat and connective tissues for meat yield determination following the Korean Hanwoo Beef Specification Guide [18].

For examination of the effect of castration method on meat quality, two representative muscles (L. lumborum and semimembranosus) were used. The meat samples were then cut into sub-samples depending on analyses in which the chemical composition, color, shear force, $\mathrm{pH}$ and water holding capacity (WHC) were performed on fresh sub-samples (the sampling day), and vacuum packed and storage frozen $\left(-20^{\circ} \mathrm{C}\right)$ sub-samples were used for analysis of fatty acids, metabolites, and volatile aroma compounds.

\section{Proximate composition}

The moisture, fat, protein, and collagen contents were analyzed following the AOAC Official Methods 2007.04 by using a Food Scan Lab 78810 (Foss Tecator Co., Ltd., Hillerod, Denmark). Briefly, about $200 \mathrm{~g}$ of ground meat sample (each) was distributed onto the round dish which was then loaded into the instrument's sample chamber. Based on the precalibrated ranges of moisture, protein, fat, and collagen for meat category by manufacturer, these contents were automatically measured and expressed as percentage. Each sample was determined in duplicate.

\section{pH measurement}

The $\mathrm{pH}$ values of samples were measured in triplicate using 
a $\mathrm{pH}^{\star} \mathrm{K} 21$ meter (NWK-Technology GmbH, Kaufering, Germany) equipped with a stainless steel and solid-state probe. The $\mathrm{pH}$ measurement was done by inserting the probe deeply into the muscle tissues. Prior to use, the $\mathrm{pH}$ meter was calibrated with pH 4.0 and 7.0 standard solutions (NWK Technology., Germany).

\section{Meat color and Warner-Bratzler shear force}

The color and Warner-Bratzler shear force (WBSF) were measured on a same transverse section ( $3.0 \mathrm{~cm}$-thick steak) of each the sample. For the color, after a 30 min blooming period at $4^{\circ} \mathrm{C}$, it was measured on three different locations of each sample using a standardized Minolta Chroma Meter CR-400 with a D65 illuminant ${ }^{*} \mathrm{C}$ and $2^{\circ}$ observer (Minolta Camera Co, Osaka, Japan). The color was measured under white lighting and the results were reported as $\mathrm{CIE} \mathrm{L}^{\star}$ (lightness), CIE $\mathrm{a}^{*}$ (redness), and CIE $\mathrm{b}^{*}$ (yellowness).

For the WBSF analysis, it was carried out following our previous procedure [19]. The samples were placed into individual plastic bags, sealed with double clip, and placed in a $72^{\circ} \mathrm{C}$ pre-heated water bath until the core temperature reached $70^{\circ} \mathrm{C}$. Immediately after cooking, the cooked samples were cooled for $30 \mathrm{~min}$ under running water and each sample was made into 5 strips parallel to the muscle fiber direction using a 0.5 -inch metal corer. The WBSF values were obtained by completely cutting the strips using a Instron Universal Testing Machine (Model 4465, Instron Corp, High Wycombe, UK) at a crosshead speed of $200 \mathrm{~mm} / \mathrm{min}$ and a $40 \mathrm{~N}$ load cell.

\section{Fatty acid composition}

The sample preparation for fatty acids analysis was performed following the procedure as described in our previous study [19]. Briefly, each sample (Ca.10 g) was weighed and homogenized with $150 \mathrm{~mL}$ of chloroform: methanol (2:1, v/v) solvent mixture at $300 \times \mathrm{g}$ for $3 \mathrm{~min}$ using a homogenizer (Polytron, PT-MRC 2100, Littau, Switzerland). After filtration through Whatman filter paper, the filtrate was added with approximately $20 \mathrm{~g}$ of $\mathrm{Na}_{2} \mathrm{SO}_{4}$, thoroughly mixed for 1 $\mathrm{min}$, and then the upper lipid layer was transferred into an Erlenmeyer flask. After drying at $55^{\circ} \mathrm{C}$ using a rotary evaporator, the lipids layer was reconstituted with $1 \mathrm{~mL}$ tricosanoic acid and $1 \mathrm{~mL}$ of $0.5 \mathrm{~N} \mathrm{NaOH}$. Finally, the lipid was converted to fatty acid methyl esters (FAMEs). Approximately $1.0 \mathrm{~mL}$ of FAMEs was taken and placed into auto-sampler vials, sealed, and used for fatty acids analysis. The separation of FAMEs was achieved using a gas chromatography/flame ionization detector (GC-FID; Varian Technologies, Palo Alto, CA, USA) equipped with an Omegawax capillary column (30 $\mathrm{m} \times 0.25 \mathrm{~mm} \times 0.25 \mu \mathrm{m}$ film thickness; Supelco, Bellefonte, PA, USA) as described in our previous study [19]. Identification of fatty acids in the samples was carried out by comparing their retention times with those obtained from standard fatty acids. Individual fatty acids were expressed as relative percent (\%) of total fatty acids.

\section{Metabolites analysis by NMR Spectroscopy}

The analysis of metabolites was performed using the protocol as described in our previous study [20] with suitable modification. Approximately $20 \mathrm{mg}$ of each sample was weighted and extracted with acetonitrile/water $(1: 1, \mathrm{v} / \mathrm{v})$ mixture on ice for $10 \mathrm{~min}$. The samples were centrifuged at $3,000 \times \mathrm{g}$ for $10 \mathrm{~min}$ at $4^{\circ} \mathrm{C}$, and the supernatant was collected and freeze-dried. The lyophilized samples were dissolved in $700 \mu \mathrm{L}$ of deuterated water containing $2 \mathrm{mM} 3$-trimethylsilyl2,2,3,3-tetradeuteropropionicacid-d4 (TSP-d4; Sigma-Aldrich, St. Louis, MO, USA) as an internal reference, and then was transferred into a $5 \mathrm{~mm}$ NMR tube for analysis. ${ }^{1} \mathrm{H}-\mathrm{NMR}$ spectra were acquired on a $600 \mathrm{MHz}$ Agilent NMR spectrometer (Agilent Technologies, Palo Alto, CA, USA) equipped with $600 \mathrm{MHz}$ 4-mm gHX NanoProbe (Agilent Technologies, Santa Clara, CA, USA) at a ${ }^{1} \mathrm{H}$ frequency of $599.93 \mathrm{MHz}$. The ${ }^{1} \mathrm{H}-\mathrm{NMR}$ conditions set were the same as those described in our previous study [20]. The acquired spectra were phased and then the baseline was corrected and referenced to the TSP-d4 peak using a Vnmrj (version 4.2, Agilent Technologies, USA). Metabolites in the ${ }^{1} \mathrm{H}-\mathrm{NMR}$ spectra were tentatively identified using Chenomx $600 \mathrm{MHz}$ library database and Chenomx NMR Suite 7.1 professional (Chenomx Inc., Edmonton, Canada). The identified metabolites were expressed as percentage of the normalized area.

\section{Free amino acids and nucleotides analysis}

The free amino acids (FAAs) content in the samples was analyzed following the procedure as described by Cho et al [20] with suitable modifications. Briefly, $5.0 \mathrm{~g}$ of each sample was weighted and homogenized with $10 \mathrm{~mL}$ distilled water at $11,000 \times \mathrm{g}$ for $30 \mathrm{~s}$. After centrifuging at $10,000 \times \mathrm{g}$ for $10 \mathrm{~min}$ at $4^{\circ} \mathrm{C}, 100 \mu \mathrm{L}$ of supernatant was taken and mixed with 900 $\mu \mathrm{L}$ methanol containing $0.1 \%$ formic acid. The samples were again centrifuged at $10,000 \times \mathrm{g}$ for $10 \mathrm{~min}$ at $4^{\circ} \mathrm{C}$, and about $500 \mu \mathrm{L}$ of supernatant was injected into a Waters ACQUITY UPLC (model: Xevo TQ-S; Waters Co. Milford, MA, USA) connected to an Imtaka Intrada Amino Acid column: $2 \times 50$ mm, $3 \mu \mathrm{m}$ (Imtaka, Uphur St, Suite A, Portland). The eluents used were A (acetonitrile: $100 \mathrm{mM}$ ammonium formate; 20:80 v/v) and B (acetonitrile: trifluoroacetic acid: $25 \mathrm{mM}$ ammonium formate: formic acid: 9:75:16:03 v/v/v). The separation was carried out at $37^{\circ} \mathrm{C}$ and flowing rate of $0.4 \mathrm{~mL} /$ min, and solvent gradient: initial $100 \% \mathrm{~B}$, linear change to $83 \%$ B for 6.5 min, linear change to $100 \%$ A for 3.5 min and then linear change to $100 \% \mathrm{~B}$ for $2 \mathrm{~min}$, and maintained for additional $5 \mathrm{~min}$. The amino acids standard was used for identifying and quantifying the FAA in the samples, and the 
detected FAA were expressed as milligram per $100 \mathrm{~g}$ meat (mg/100 g meat).

\section{Volatile aroma compounds analysis}

Volatile aroma compounds in cooked meat samples were analyzed using the procedure as described in our previous study [21]. The samples were cooked at around $180^{\circ} \mathrm{C}$ on an open tin-coated grill for about $2 \mathrm{~min}$, and proximately $2.0 \mathrm{~g}$ of each the cooked samples were weighed, placed into 20$\mathrm{mL}$ headspace vial (Agilent, USA) and tightly capped with PTFE-faced silicone septum prior to the analysis. The volatile compounds were extracted using solid-phase micro-extraction (SPME) technique. The vials containing samples were extracted for volatile compounds using the SPME technique. For this, a SPME device with carboxen-polydimethylsiloxane $(75 \mu \mathrm{m})$ fiber (Supelco, USA) was inserted into the vials and held for $50 \mathrm{~min}$ at $60^{\circ} \mathrm{C}$. All the extraction steps were carried out using an SPME auto-sampler (model: PAL RSI 85; Agilent Technologies, Santa Clara, CA, USA) connected to a gas chromatography (model: 8890 GC system; Agilent Technologies, USA) with mass spectrophotometry (5977B MSD; Agilent Technologies, USA). Immediately after the extraction, the fiber was desorbed for $5 \mathrm{~min}$ at $250^{\circ} \mathrm{C}$, and the compounds were separated on a DB-5MS capillary column (30 $\mathrm{m} \times 0.25 \mathrm{~mm}$ i.d. $\times 0.25 \mu \mathrm{m}$ film thickness: Agilent J \& W Scientific, Folcom, CA, USA) using helium as a carrier gas. The GC oven was programmed to $40^{\circ} \mathrm{C}$ for $5 \mathrm{~min}$ and then increased to $250^{\circ} \mathrm{C}$ at a rate of $8^{\circ} \mathrm{C} / \mathrm{min}$ and held at this temperature for further $5 \mathrm{~min}$. The MS conditions set were capillary direct interface temperature, $250^{\circ} \mathrm{C}$, scanning mass range of 30 to $500 \mathrm{amu}$ and rate at $5.27 \mathrm{scans} / \mathrm{s}$. The volatile compounds were identified by using the Wiley reg- istry library (Agilent Technologies, USA) and/or by external standards. The qualification of the identified compounds was done by using a concentration-known internal standard (1.0 $\mu \mathrm{L}$ of 2-methyl-3-heptanone, $816 \mathrm{mg} / \mathrm{mL}$ in methanol).

\section{Statistical analysis}

The statistical analysis system (SAS) package (SAS Institute, Cary, NC, USA, 2015) was applied for analysis of the data. The data were analyzed by using the General Linear Model procedure of the SAS, and the castration method was considered as the main effect while the quality traits examined were considered random in the model. Means were compared using Duncan's multiple range test. Significance was set at $\mathrm{p}<0.05$. Principal component analysis (PCA) was also used to explore relationships between the variables (meat and fat yield and selected quality traits) and castration groups using the XLSTAT program 2020.3 (Addinsoft Inc., NY, USA). In this PCA model, the data obtained from both the L. lumborum and semimembranosus muscles in each castration group were averaged for each the selected variables.

\section{RESULTS AND DISCUSSION}

\section{Effects on meat yield}

The effect of castration on the meat yield of primal cuts are shown in Table 1. As expected, though the slaughter weight did not differ between the two groups the meat yield (weight and percentage) of all primal cuts (except the rib) were significantly $(\mathrm{p}<0.05)$ higher in the HC group compared to the CC group. As a result, the total meat yield was significantly higher in the HC group (303.32 kg, corresponding to $67.88 \%$ ) compared to the CC group $(259.30 \mathrm{~kg}$, corresponding to

Table 1. Carcass traits and meat yield of primal cuts of Hanwoo cattle as affected by castration method

\begin{tabular}{|c|c|c|c|c|c|c|c|c|}
\hline Items & $\begin{array}{l}\text { Complete } \\
\text { castration }\end{array}$ & Half-castration & $\begin{array}{l}\text { Complete } \\
\text { castration }\end{array}$ & Half-castration & $\begin{array}{l}\text { Complete } \\
\text { castration }\end{array}$ & Half-castration & $\begin{array}{l}\text { Complete } \\
\text { castration }\end{array}$ & Half-castration \\
\hline \multicolumn{9}{|l|}{ Slaughter and carcass weight } \\
\hline Slaughter weight (kg) & $678.40 \pm 58.16$ & $702.20 \pm 39.12$ & & & & & & \\
\hline Hot carcass weight (kg) & $421.18 \pm 46.15$ & $433.22 \pm 24.47$ & & & & & & \\
\hline Cold carcass weight (kg) & $418.08 \pm 45.99$ & $434.35 \pm 23.87$ & & & & & & \\
\hline \multirow[t]{2}{*}{ Dressing percentage (\%) } & $62.58 \pm 1.14$ & $62.85 \pm 1.56$ & & & & & & \\
\hline & \multicolumn{4}{|c|}{ Meat yield } & \multicolumn{4}{|c|}{ Trimmed fat yield } \\
\hline Primal cuts & \multicolumn{2}{|c|}{ Weight $(\mathrm{kg})$} & \multicolumn{2}{|c|}{ Percentage (\%) } & \multicolumn{2}{|c|}{ Weight $(\mathbf{k g})$} & \multicolumn{2}{|c|}{ Percentage (\%) } \\
\hline Tenderloin & $6.65 \pm 0.78^{b}$ & $7.58 \pm 0.59^{a}$ & $1.59 \pm 0.15^{b}$ & $1.75 \pm 0.13^{\mathrm{a}}$ & $2.76 \pm 0.65$ & $2.56 \pm 0.54$ & $0.66 \pm 0.14$ & $0.59 \pm 0.11$ \\
\hline Loin & $32.36 \pm 3.34^{b}$ & $38.11 \pm 3.33^{\mathrm{a}}$ & $7.76 \pm 0.46^{b}$ & $8.77 \pm 0.60^{\mathrm{a}}$ & $7.85 \pm 1.65^{\mathrm{a}}$ & $4.65 \pm 1.11^{b}$ & $1.87 \pm 0.28^{\mathrm{a}}$ & $1.07 \pm 0.24^{b}$ \\
\hline Striploin & $9.38 \pm 0.95^{b}$ & $10.40 \pm 0.69^{a}$ & $2.25 \pm 0.20^{b}$ & $2.39 \pm 0.11^{\mathrm{a}}$ & $3.46 \pm 0.78^{\mathrm{a}}$ & $2.17 \pm 0.82^{b}$ & $0.83 \pm 0.16^{\mathrm{a}}$ & $0.50 \pm 0.18^{b}$ \\
\hline Chuck roll & $18.49 \pm 2.93^{b}$ & $28.61 \pm 3.56^{\mathrm{a}}$ & $4.42 \pm 0.50^{b}$ & $6.59 \pm 0.77^{a}$ & $2.68 \pm 0.87^{a}$ & $1.81 \pm 0.57^{b}$ & $0.64 \pm 0.20^{\mathrm{a}}$ & $0.42 \pm 0.12^{b}$ \\
\hline Clod & $25.22 \pm 2.53^{b}$ & $30.40 \pm 2.18^{a}$ & $6.05 \pm 0.35^{b}$ & $7.01 \pm 0.49^{\mathrm{a}}$ & $8.40 \pm 1.68^{a}$ & $6.12 \pm 1.38^{b}$ & $2.01 \pm 0.34^{\mathrm{a}}$ & $1.41 \pm 0.30^{b}$ \\
\hline Top round & $21.80 \pm 2.09^{b}$ & $27.06 \pm 1.75^{\mathrm{a}}$ & $5.24 \pm 0.51^{b}$ & $6.24 \pm 0.39^{a}$ & $5.16 \pm 1.33^{\mathrm{a}}$ & $4.24 \pm 1.10^{b}$ & $1.22 \pm 0.24^{\mathrm{a}}$ & $0.97 \pm 0.22^{b}$ \\
\hline Bottom round & $35.63 \pm 3.87^{b}$ & $41.23 \pm 3.13^{\mathrm{a}}$ & $8.54 \pm 0.66^{b}$ & $9.50 \pm 0.58^{a}$ & $9.70 \pm 1.86^{\mathrm{a}}$ & $6.95 \pm 1.71^{b}$ & $2.30 \pm 0.25^{\mathrm{a}}$ & $1.60 \pm 0.37^{b}$ \\
\hline Brisket & $43.29 \pm 6.16^{b}$ & $49.91 \pm 4.46^{\mathrm{a}}$ & $10.34 \pm 0.63^{b}$ & $11.49 \pm 0.70^{\mathrm{a}}$ & $54.09 \pm 10.04^{\mathrm{a}}$ & $37.12 \pm 7.68^{b}$ & $12.89 \pm 1.57^{\mathrm{a}}$ & $8.52 \pm 1.55^{b}$ \\
\hline Shank & $15.88 \pm 1.61^{b}$ & $17.91 \pm 1.40^{\mathrm{a}}$ & $3.81 \pm 0.27^{b}$ & $4.13 \pm 0.28^{a}$ & $3.55 \pm 0.64^{a}$ & $2.89 \pm 0.64^{b}$ & $0.85 \pm 0.13^{\mathrm{a}}$ & $0.66 \pm 0.13^{b}$ \\
\hline Rib & $50.61 \pm 5.79$ & $52.10 \pm 3.13$ & $12.11 \pm 0.46$ & $12.01 \pm 0.61$ & $11.88 \pm 3.47^{\mathrm{a}}$ & $6.77 \pm 1.96^{b}$ & $2.81 \pm 0.60^{a}$ & $1.55 \pm 0.42^{b}$ \\
\hline Total meat/fat yield & $259.30 \pm 3.05^{b}$ & $303.32 \pm 2.42^{\mathrm{a}}$ & $62.11 \pm 0.41^{b}$ & $67.88 \pm 0.46^{\mathrm{a}}$ & $109.53 \pm 2.29^{a}$ & $75.28 \pm 1.75^{b}$ & $26.08 \pm 0.39^{a}$ & $17.29 \pm 0.36^{b}$ \\
\hline
\end{tabular}

$a, b$ Means within a same row in each parameter with different superscripts are significantly different $(p<0.05)$. 
$62.11 \%)(\mathrm{p}<0.05)$. Thus, the total meat yield of the HC groups was about $44 \mathrm{~kg}$ more than the CC group. Contrastingly, a significantly higher trimmed fat level (weight and yield percentage) was found in almost all primal cuts from the CC group compared to the $\mathrm{HC}$ group $(\mathrm{p}<0.05)$. The total trimmed fat in the CC group was about $34 \mathrm{~kg}$ more than the HC group, indicating a higher fat deposition level in these completely castrated animals. In the present study, the animals were raised under identical conditions and fed a same dietary regime, therefore, the results indicating the higher meat yield and lower trimmed fat amount in the HC group could be attributed to its higher residual serum testosterone levels (the serum testosterone level remained in the HC group was around $10 \mathrm{ng} / \mathrm{mL}$ throughout the trial period whereas, it remained less than $1.0 \mathrm{ng} / \mathrm{mL}$ in the CC group, data not shown). Because testosterone promotes the muscular development by interacting with receptors in DNA which results in an increased protein synthesis [16]. This finding agrees well with that of Marti et al [22], who showed a positive correlation between the residual serum testosterone level and body weight gain of immunologically castrated cattle. Thus, it may be said that half-castration could be considered as an alternative practice for increasing the meat yield of castrated animals in the beef industry.

Effects on chemical composition and quality traits The chemical composition and quality traits of two muscles as affected by castration and their comparison with intact males (bulls) are shown in Table 2. In both the muscles examined, the HC animals had significantly $(\mathrm{p}<0.05)$ higher protein contents compared to the CC animals. However, when compared to the protein content in intact males, these protein levels were lower $(\mathrm{p}<0.05)$. This could be related to the higher serum testosterone level which increased the muscular protein synthesis in these half-castrated animals [16]. IMF (fat present within the lean) is known as the important factor determining overall meat quality [6]. Our results showed that the CC group exhibited significantly higher fat content $(17.53 \%$ and $10.13 \%$ in the L. lumborum and semimembranosus muscles, respectively) compared to the HC group $(8.02 \%$ and $4.28 \%$ in the L. lumborum and semimembranosus muscles, respectively) $(\mathrm{p}<0.05)$. Especially, the fat levels in the muscles of $\mathrm{HC}$ animals were almost two times greater compared to those of intact males $(\mathrm{p}<0.05)$. In general, the fat contents in both muscles were in the following order: $\mathrm{CC}>\mathrm{HC}>$ intact males. This indicates that not only the complete castration, but the half-castration method also caused an increased degree of fat deposition in the muscle tissues when compared to the bulls. The results indicating the increased IMF deposition in the castrated males could be attributed to the lower residual serum sex hormones such as testosterone [22] because this hormone is responsible for the adipose tissue distribution, adipogenesis as well as adipocyte mechanism regulations [23], especially the testosterone has an anti-adipogenic effect on the adipose tissue [24]. Compared with fat levels in Longissimus muscles from castrated Friesian cattle (around 4.5\%) reported by Prado et al [11] and 1/2 Nelore $\times 1 / 2$ Aberdeen Angus steers (3.38\%) reported by das Gracas Padre et al [25] the half-castrated cattle in the present study had a higher level.

The $\mathrm{pH}$ and $\mathrm{WHC}$ is an important technological quality trait of meat. Our results showed that the $\mathrm{pH}$ values in both muscles did not differ between the HC and CC groups ( $p>$ 0.05 ). This indicated that the rate of postmortem $\mathrm{pH}$ decline

Table 2. Chemical composition and technological quality traits of $L$. lumborum and semimembranosus muscles as affected by castration method

\begin{tabular}{|c|c|c|c|c|c|c|}
\hline \multirow[b]{2}{*}{ Items } & \multicolumn{3}{|c|}{ L. lumborum } & \multicolumn{3}{|c|}{ S. semimembranosus } \\
\hline & Intact males ${ }^{1)}$ & $\begin{array}{l}\text { Complete } \\
\text { castration }\end{array}$ & Half-castration & Intact males ${ }^{1)}$ & $\begin{array}{l}\text { Complete } \\
\text { castration }\end{array}$ & Half-castration \\
\hline \multicolumn{7}{|c|}{ Chemical composition } \\
\hline Moisture (\%) & $70.21 \pm 2.12^{a}$ & $62.10 \pm 4.24^{c}$ & $67.21 \pm 3.21^{b}$ & $71.38 \pm 1.54^{a}$ & $67.21 \pm 3.21^{b}$ & $70.43 \pm 2.02^{a}$ \\
\hline Fat $(\%)$ & $4.20 \pm 1.48^{c}$ & $16.45 \pm 6.62^{\mathrm{a}}$ & $8.02 \pm 4.03^{b}$ & $2.49 \pm 0.97^{c}$ & $8.02 \pm 4.03^{\mathrm{a}}$ & $4.28 \pm 2.39^{b}$ \\
\hline Protein (\%) & $21.30 \pm 1.55^{a}$ & $18.75 \pm 1.57^{\circ}$ & $20.70 \pm 0.92^{b}$ & $21.58 \pm 1.61^{\mathrm{a}}$ & $20.07 \pm 0.92^{c}$ & $21.11 \pm 0.69^{b}$ \\
\hline \multicolumn{7}{|c|}{ Technological quality traits } \\
\hline $\mathrm{pH}$ & $5.82 \pm 0.11^{a}$ & $5.54 \pm 0.01^{b}$ & $5.53 \pm 0.02^{b}$ & $5.89 \pm 0.05^{a}$ & $5.50 \pm 0.03^{b}$ & $5.49 \pm 0.02^{b}$ \\
\hline WHC (\%) & $55.25 \pm 5.34^{a}$ & $46.67 \pm 4.44^{b}$ & $46.00 \pm 5.85^{b}$ & $53.89 \pm 6.43^{a}$ & $45.77 \pm 4.74^{b}$ & $45.83 \pm 4.98^{b}$ \\
\hline Shear force $(\mathrm{kg})$ & $7.72 \pm 1.17^{\mathrm{a}}$ & $5.54 \pm 1.20^{b}$ & $5.68 \pm 1.03^{b}$ & $7.02 \pm 1.32^{\mathrm{a}}$ & $5.17 \pm 1.17^{\mathrm{b}}$ & $5.92 \pm 1.05^{\mathrm{c}}$ \\
\hline L* (Lightness) & $33.53 \pm 3.70^{c}$ & $39.89 \pm 4.35^{\mathrm{a}}$ & $36.50 \pm 2.50^{b}$ & $34.11 \pm 4.39^{b}$ & $37.70 \pm 3.28^{a}$ & $36.23 \pm 2.68^{\mathrm{ab}}$ \\
\hline$a^{*}$ (Redness) & $18.32 \pm 2.22^{a}$ & $17.44 \pm 2.03^{b}$ & $16.28 \pm 2.24^{c}$ & $22.09 \pm 4.49^{a}$ & $18.37 \pm 2.62^{b}$ & $17.86 \pm 2.12^{b}$ \\
\hline$b^{\star}$ (Yellowness) & $7.94 \pm 1.33^{b}$ & $8.34 \pm 1.28^{a}$ & $7.46 \pm 1.07^{b}$ & $10.23 \pm 2.97^{a}$ & $8.81 \pm 1.82^{b}$ & $8.32 \pm 1.34^{b}$ \\
\hline
\end{tabular}

WHC, water holding capacity.

1) The data used in the statistical model was obtained from the same muscles at same post-slaughter period ( $24 \mathrm{~h}$ ) of intact males (harvested at 25.74 months of age, body weight of $728 \mathrm{~kg}$, raised under identical conditions) of the same cattle breed (Hanwoo) in another of our research projects (Project No. PJ01212501)

${ }^{a-c}$ Means within a same row in each muscle with different superscripts are significantly different $(p<0.05)$. 
was similar for both castration groups. Similarly, no differences in WHC occurred between the HC and CC groups ( $p>0.05)$. However, compared with the meat of intact males, both the HC- and CC-derived meat exhibited a lower WHC $(p<0.05)$. It is well known that WHC of meat is greatly affected by $\mathrm{pH}$; a slower rate of $\mathrm{pH}$ decline or a higher $\mathrm{pH}$ value results in a better $\mathrm{WHC}$ of the meat by creating a charge imbalance [26]. Thus, the results indicating the higher WHC of meat from intact males may be related to its higher $\mathrm{pH}$ value.

There has been an increasing interest in the improvement of meat tenderness by producers as it is considered as the important qualitative trait determining acceptability, satisfaction and willingness-to-pay premium prices [5]. Among the meat tenderness evaluation methods, the WBSF is a highly reliable method for objective evaluation of beef tenderness [27]. Results showed that there were no differences in the WBSF values in the L. lumborum muscles between the HC $(5.68 \mathrm{~kg})$ and $\mathrm{CC}(5.54 \mathrm{~kg})$ groups ( $>0.05)$, but in the semimembranosus muscle the WBSF value was high in the HC $(5.92 \mathrm{~kg})$ compared to CC group $(5.17 \mathrm{~kg})(\mathrm{p}<0.05)$. However, compared to the WBSF values in both the muscles (7.72 and $7.02 \mathrm{~kg}$ for the L. lumborum and semimembranosus muscles, respectively) from the intact males, both the $\mathrm{HC}$ and $\mathrm{CC}$ animals showed significantly lower values $(\mathrm{p}<0.05)$. According to the classification of beef tenderness proposed by Boleman et al [28] both the muscles from the HC and CC groups could be considered as 'moderate' whereas, the meat from intact males could be considered as 'tough' (5.90 to $7.21 \mathrm{~kg}$ ). This indicates that not only the complete castration the halfcastration method also showed its beneficial effects on the improvement of meat tenderness. This could be related to the castration which resulted in the reduced physical and sexual behavior activity [9], and an increased fat content because the level fat has been found to positively correlate with the tenderness [19]. Compared with our data, Destefanis et al [29] and Amatayakul-Chantler et al [30] reported higher shear force values (7.15 to $9.07 \mathrm{~kg}$ ) in same muscle from castrated Piemontese and Bos indicus cattle.

Consumers consider color as the most important indicator of freshness and wholesomeness of meat. Regarding the $L^{*}$ (lightness), the CC group showed higher values in the $L$. lumborum muscles $(\mathrm{p}<0.05)$, but no differences occurred between the two castration groups for the semimembranosus muscles $(\mathrm{p}>0.05)$. For the $\mathrm{a}^{*}$ (redness), there were no differences in the values between the HC and CC groups for both L. lumborum and semimembranosus muscles ( $\mathrm{p}>0.05$ ). It is worth noting that the $\mathrm{HC}$ or $\mathrm{CC}$ castration resulted in a better color (lighter color) compared to the intact males that presented a darker color (indicated by lower $\mathrm{L}^{\star}$ and higher $a^{*}$ values $)(p<0.05)$. This could be related to the higher fat content in these meat sample groups whereas, the darker color of intact male meat may be due to a high level of serum testosterone which results in greater connective tissue and hemoglobin contents in the meat [14].

\section{Effects on fatty acid profiles}

Fatty acid profiles not only reflect the nutritional value but also remarkably influence the development of meat flavor during cooking [31]. This study for first time investigated the fatty acid profiles in meat from half-castrated cattle. The outcome of our analysis (Table 3) depicts that the HC group contained lower levels of saturated fatty acids (SFA) such as myristic acid (C14:0) and palmitic acid (C16:0), and higher levels of unsaturated fatty acids such as linoleic acid (C18:2n6), gamma linoleic acid(C18:3n6) and linolenic acid (C18:3n3) in the L. lumborum muscles $(\mathrm{p}<0.05)$. A similar trend was also observed in the semimembranosus muscles in which the HC group contained higher levels of unsaturated fatty acids such as C18:2n6, C18:3n6 and arachidonic acid (C20:4n6) compared to the CC group ( $\mathrm{p}<0.05)$. As a result, the total polyunsaturated fatty acid (PUFA) and n-3 PUFA contents as well as PUFA/SFA value in both muscles were higher in the HC group compared to the CC group $(\mathrm{p}<0.05)$. In general, research conducted to examine the effects of castration on fatty acid profiles in beef have also shown that castration caused alterations of fatty acid profiles in which a lower PUFAs and a higher monounsaturated fatty acids (MUFAs) content was observed in steers compared to bulls $[14,25]$. Compared to our data, however, these researchers found a lower MUFAs content (39\% to $42 \%$ ), this could be related to the feeding diet and genetic differences among the studies.

From a human nutritional point of view, dietary n-3 PUFAs has long been known to have many beneficial effects on physiological processes, and a healthy diet should have a high PUFA/SFA and a low n-6/n-3 ratio [32]. Furthermore, MUFAs such as oleic acid (C18:1n9) plays an important role in cooked meat flavor development [33]. As aforementioned, meat of castrated males (steer) usually contains a higher MUFAs content compared to bulls [14,25]. It is worth noting that in both the muscles studied, the most dominant MUFA such as $\mathrm{C} 18: \ln 9$ that was not different between the $\mathrm{HC}$ and CC groups ( $p>0.05)$. Overall, it may be said that the meat from half-castrated animals were improved in term of nutritional value by increasing the PUFAs content while their MUFAs content was comparable to that of meat from the completely castrated animals (steers).

\section{Effects on taste-related compounds (free amino acids and metabolites)}

The concentrations of FAAs in the L. lumborum and semimembranosus muscles from two castration groups are presented in Table 4. FAAs are known as amino acids that are present in meat in the free form. FAAs play an important role eliciting 
Table 3. Fatty acid profiles (\% of total fatty acids) of L. lumborum and semimembranosus muscles as affected by castration method

\begin{tabular}{|c|c|c|c|c|}
\hline \multirow{2}{*}{ Item } & \multicolumn{2}{|c|}{ L. Iumborum } & \multicolumn{2}{|c|}{ M. semimembranosus } \\
\hline & Half-castration & Complete castration & Half-castration & Complete castration \\
\hline C14:0 & $2.63 \pm 0.47^{b}$ & $3.17 \pm 0.69^{a}$ & $2.68 \pm 1.49$ & $2.86 \pm 0.69$ \\
\hline C16:0 & $26.94 \pm 1.92^{b}$ & $28.83 \pm 1.84^{a}$ & $30.38 \pm 10.19$ & $30.87 \pm 2.93$ \\
\hline $\mathrm{C} 16: 1 \mathrm{n} 7$ & $3.24 \pm 0.71$ & $3.59 \pm 0.64$ & $3.24 \pm 1.51$ & $3.59 \pm 0.84$ \\
\hline C18:0 & $12.86 \pm 1.81$ & $11.54 \pm 1.41$ & $13.47 \pm 3.03$ & $11.92 \pm 1.54$ \\
\hline C18:1n9 & $50.82 \pm 3.55$ & $50.50 \pm 2.23$ & $51.91 \pm 16.12$ & $48.15 \pm 3.98$ \\
\hline C18:1n7 & $0.31 \pm 0.11$ & $0.40 \pm 0.14$ & $0.21 \pm 0.09^{b}$ & $0.34 \pm 0.14^{a}$ \\
\hline C18:2n6 & $2.65 \pm 1.03^{\mathrm{a}}$ & $1.65 \pm 0.31^{b}$ & $4.44 \pm 2.57^{\mathrm{a}}$ & $1.89 \pm 0.29^{b}$ \\
\hline C18:3n6 & $0.02 \pm 0.01^{a}$ & $0.01 \pm 0.01^{b}$ & $0.01 \pm 0.01$ & $0.01 \pm 0.00$ \\
\hline C18:3n3 & $0.06 \pm 0.02^{\mathrm{a}}$ & $0.03 \pm 0.01^{b}$ & $0.09 \pm 0.03^{a}$ & $0.03 \pm 0.01^{b}$ \\
\hline C20:1n9 & $0.23 \pm 0.12$ & $0.18 \pm 0.08$ & $0.17 \pm 0.08$ & $0.16 \pm 0.06$ \\
\hline C20:4n6 & $0.21 \pm 0.28$ & $0.07 \pm 0.03$ & $0.79 \pm 0.84^{\mathrm{a}}$ & $0.15 \pm 0.07^{b}$ \\
\hline C20:5n3 & $0.00 \pm 0.01$ & $0.00 \pm 0.00$ & $0.01 \pm 0.02$ & nd \\
\hline $\mathrm{C} 22: 4 \mathrm{n} 6$ & $0.03 \pm 0.02$ & $0.02 \pm 0.01$ & $0.07 \pm 0.05$ & $0.03 \pm 0.01$ \\
\hline SFA & $42.43 \pm 3.58$ & $43.55 \pm 1.75$ & $43.24 \pm 3.66$ & $45.65 \pm 3.03$ \\
\hline UFA & $57.57 \pm 3.58$ & $56.45 \pm 1.75$ & $56.76 \pm 3.66$ & $54.35 \pm 3.03$ \\
\hline MUFA & $54.60 \pm 3.68$ & $54.67 \pm 1.89$ & $51.51 \pm 3.44$ & $52.24 \pm 3.21$ \\
\hline PUFA & $2.97 \pm 1.32^{a}$ & $1.78 \pm 0.34^{b}$ & $5.25 \pm 3.56^{a}$ & $2.11 \pm 0.32^{b}$ \\
\hline n3 & $0.06 \pm 0.02^{\mathrm{a}}$ & $0.03 \pm 0.01^{b}$ & $0.09 \pm 0.05^{a}$ & $0.03 \pm 0.01^{b}$ \\
\hline n6 & $2.91 \pm 1.30^{a}$ & $1.75 \pm 0.33^{b}$ & $5.16 \pm 3.52^{\mathrm{a}}$ & $2.08 \pm 0.31^{b}$ \\
\hline n6/n3 & $51.70 \pm 10.95$ & $60.27 \pm 19.13$ & $53.25 \pm 14.32$ & $63.47 \pm 16.97$ \\
\hline MUFA/SFA & $1.30 \pm 0.19$ & $1.26 \pm 0.10$ & $1.20 \pm 0.16$ & $1.15 \pm 0.16$ \\
\hline PUFA/SFA & $0.07 \pm 0.03^{\mathrm{a}}$ & $0.04 \pm 0.01^{b}$ & $0.13 \pm 0.10^{\mathrm{a}}$ & $0.05 \pm 0.01^{b}$ \\
\hline
\end{tabular}

nd, not detectable; SFA, saturated fatty acid; UFA, unsaturated fatty acid; MUFA, monounsaturated fatty acid; PUFA, polyunsaturated fatty acid.

$a, b$ Means within a same row in each muscle with different superscripts are significantly different $(p<0.05)$.

Table 4. Concentration (mg/100 g) of free amino acids of L. lumborum and semimembranosus muscles as affected by castration method

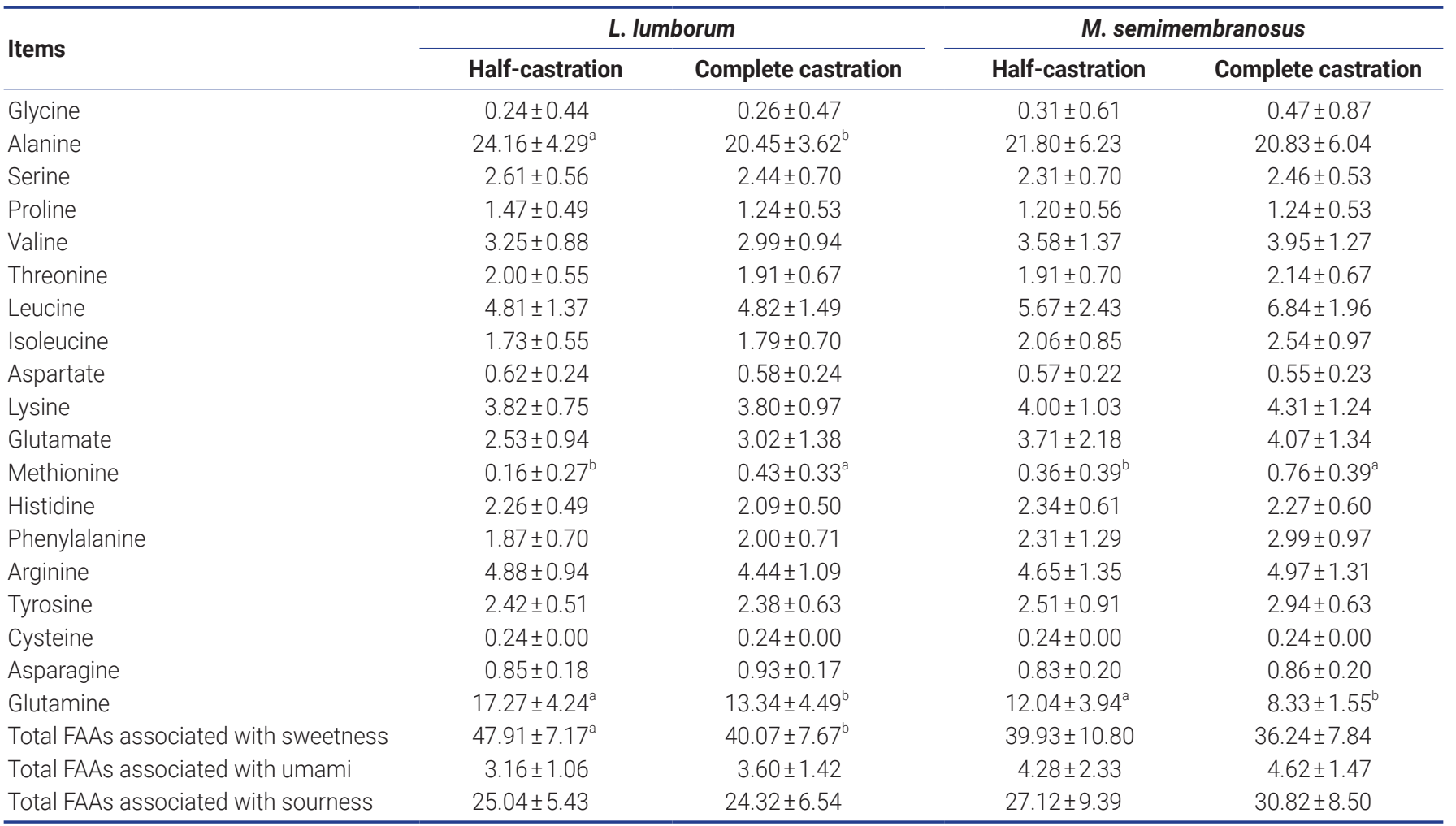

SM, semimembranosus; FAAs, free amino acids.

${ }_{a, b}$ Means within a same row in each muscle with different superscripts are significantly different $(p<0.05)$. 
tastes of meat as they are rapidly detected by the proteincoupled receptors on taste cells [34]. Researchers correlated the presence of FAAs with tastes of meat such as sweetness (glycine, alanine, serine, proline and glutamic acid), umami taste (glutamic acid, aspartic acid, alanine, serine, lysine, and methionine), sourness (aspartic acid, histidine, and asparagine) and bitterness (valine, leucine, isoleucine, phenylalanine, arginine, proline, tryptophan, and methionine) $[35,36]$. Our results showed that the castration only affected amounts of 3 FAAs (alanine, methionine, and glutamine). Interestingly, the concentrations of alanine and glutamine (sweetness and umami-related compounds) were approximately $4 \mathrm{mg}$ higher in the HC group compared to the CC group ( $\mathrm{p}<0.05)$. Whereas the amount of methionine was higher in both the muscles from the CC group compared to the HC group $(\mathrm{p}<0.05)$. The most abundant FAAs we found in the muscles from both the castration groups were alanine and glutamine, which was similar to finding of Cho et al [20], who studied on the same Hanwoo beef muscle. Based on their taste contribution as above-mentioned, the total sweetness-related FAAs content was higher (by about 7 and $3 \mathrm{mg}$ in the L. lumborum and semimembranosus muscles, respectively) in the HC group compared to the CC group $(\mathrm{p}<0.05)$. While no differences in total amounts of umami-and sournessrelated FAAs occurred between the CC and HC groups $(\mathrm{p}>0.05)$.

A total of 30 metabolites were identified in the muscles from the two castration groups (Table 5). Out of them, creatine, carnitine, and creatinine are the commonly found metabolites in meat [37]. Some amino acids (alanine, glutamine, isoleucine, methionine, valine, and leucine), sugars (glucose and glucose-6-phosphate), nucleotides (inosine and inosine-5'-phosphate, IMP) and others, have been reported in beef [20]. Several of the identified metabolites such as amino acids (alanine, glutamine and methionine), free sugar (glucose) and IMP have been reported to directly contribute to sweet and umami tastes of meat [38]. It was also observed that only two compounds that showed differences $(\mathrm{p}<0.05)$

Table 5. Metabolomics profiles (\% of total metabolites) in L. lumborum and Semimembranosus muscles as affected by castration method

\begin{tabular}{|c|c|c|c|c|}
\hline \multirow{2}{*}{ Metabolites } & \multicolumn{2}{|c|}{ L. lumborum } & \multicolumn{2}{|c|}{ M. semimembranosus } \\
\hline & Complete castration & Half-castration & Complete castration & Half-castration \\
\hline Acetate & $0.45 \pm 0.13$ & $0.60 \pm 0.11$ & $0.56 \pm 0.09$ & $0.69 \pm 0.23$ \\
\hline Alanine & $1.66 \pm 0.12$ & $1.58 \pm 0.23$ & $1.69 \pm 0.35$ & $1.74 \pm 0.31$ \\
\hline Anserine & $1.81 \pm 0.24$ & $2.26 \pm 0.57$ & $2.39 \pm 0.19$ & $2.36 \pm 0.18$ \\
\hline Betaine & $0.51 \pm 0.17$ & $0.45 \pm 0.06$ & $0.45 \pm 0.17$ & $0.41 \pm 0.10$ \\
\hline Carnitine & $2.05 \pm 0.21$ & $1.81 \pm 0.52$ & $1.85 \pm 0.19$ & $1.77 \pm 0.53$ \\
\hline Creatine & $18.36 \pm 0.95$ & $18.68 \pm 0.66$ & $17.17 \pm 0.72$ & $17.52 \pm 1.26$ \\
\hline Creatinine & $0.67 \pm 0.08$ & $0.69 \pm 0.14$ & $0.79 \pm 0.21$ & $0.78 \pm 0.18$ \\
\hline Fumarate & $0.23 \pm 0.09$ & $0.46 \pm 0.29$ & $0.32 \pm 0.19$ & $0.26 \pm 0.27$ \\
\hline Glucose & $2.47 \pm 0.44^{a}$ & $1.54 \pm 0.50^{b}$ & $2.01 \pm 0.61$ & $2.04 \pm 0.52$ \\
\hline Glucose-6-phosphate & $3.45 \pm 0.68$ & $2.69 \pm 0.69$ & $3.15 \pm 0.59$ & $3.07 \pm 0.72$ \\
\hline Glutamine & $1.05 \pm 0.38$ & $1.47 \pm 0.28$ & $0.89 \pm 0.17$ & $1.23 \pm 0.37$ \\
\hline Glutathione & $0.28 \pm 0.12$ & $0.26 \pm 0.07$ & $0.24 \pm 0.11$ & $0.25 \pm 0.01$ \\
\hline Glycerol & $2.95 \pm 0.37$ & $3.34 \pm 0.41$ & $3.33 \pm 0.24$ & $3.48 \pm 0.41$ \\
\hline Glycine & $1.35 \pm 0.20$ & $1.44 \pm 0.24$ & $1.42 \pm 0.23$ & $1.42 \pm 0.23$ \\
\hline IMP & $1.25 \pm 0.54$ & $1.33 \pm 0.30$ & $1.39 \pm 0.71$ & $0.81 \pm 0.39$ \\
\hline Inosine & $0.46 \pm 0.17$ & $0.59 \pm 0.19$ & $0.53 \pm 0.32$ & $0.53 \pm 0.26$ \\
\hline Isoleucine & $0.19 \pm 0.02$ & $0.18 \pm 0.02$ & $0.23 \pm 0.05$ & $0.20 \pm 0.04$ \\
\hline Lactate & $56.71 \pm 1.62$ & $56.38 \pm 1.43$ & $57.52 \pm 0.79$ & $57.29 \pm 1.31$ \\
\hline Leucine & $0.38 \pm 0.06$ & $0.33 \pm 0.03$ & $0.41 \pm 0.06$ & $0.32 \pm 0.07$ \\
\hline Malonate & $0.54 \pm 0.10$ & $0.56 \pm 0.15$ & $0.53 \pm 0.12$ & $0.54 \pm 0.10$ \\
\hline Methionine & $0.15 \pm 0.03 b$ & $0.21 \pm 0.02^{\mathrm{a}}$ & $0.16 \pm 0.06$ & $0.18 \pm 0.08$ \\
\hline N,N-Dimethylglycine & $0.06 \pm 0.00$ & $0.07 \pm 0.00$ & $0.06 \pm 0.00$ & $0.06 \pm 0.00$ \\
\hline N-Nitrosodimethylamine & $0.22 \pm 0.02$ & $0.21 \pm 0.02$ & $0.21 \pm 0.02$ & $0.21 \pm 0.01$ \\
\hline Niacinamide & $0.27 \pm 0.04$ & $0.31 \pm 0.06$ & $0.27 \pm 0.04$ & $0.27 \pm 0.03$ \\
\hline O-Acetylcarnitine & $0.70 \pm 0.09$ & $0.77 \pm 0.16$ & $0.76 \pm 0.05$ & $0.72 \pm 0.20$ \\
\hline Pyruvate & $0.14 \pm 0.18$ & $0.09 \pm 0.08$ & $0.05 \pm 0.02$ & $0.05 \pm 0.01$ \\
\hline Succinate & $0.48 \pm 0.47$ & $0.37 \pm 0.31$ & $0.48 \pm 0.34$ & $0.47 \pm 0.39$ \\
\hline Tyrosine & $0.13 \pm 0.01$ & $0.14 \pm 0.05$ & $0.13 \pm 0.02$ & $0.14 \pm 0.03$ \\
\hline Valine & $0.26 \pm 0.03$ & $0.25 \pm 0.04$ & $0.29 \pm 0.02$ & $0.26 \pm 0.08$ \\
\hline sn-Glycero-3-phosphocholine & $0.76 \pm 0.16$ & $0.92 \pm 0.35$ & $0.74 \pm 0.16^{b}$ & $0.94 \pm 0.11^{\mathrm{a}}$ \\
\hline
\end{tabular}

a,b Means within a same row with different superscripts are significantly different $(p<0.05)$. 
between the HC and CC groups were glucose and methionine. Overall, the half-castration method caused a negligible effect on the tastes-related components such as FAAs and metabolites in the muscles studied, suggesting that the halfcastration method seems not to cause a defect or alteration of tastes of the beef.

\section{Effects on volatile flavor compounds}

Flavor comprising two sensations (taste and aroma) is very important from the eating quality point of view [39]. As a part of the cooked meat flavor, aroma (smell) is mainly generated by volatile compounds which are produced during cooking/heating [31]. Table 6 shows the concentrations ( $\mu \mathrm{g} / \mathrm{g}$

Table 6. Concentration $(\mu \mathrm{g} / \mathrm{g})$ of volatile flavor compounds in L. lumborum muscles as affected by castration method

\begin{tabular}{|c|c|c|c|c|}
\hline Compounds & Retention time (min) & $\mathrm{IM}^{1)}$ & Complete castration & Half-castration \\
\hline \multicolumn{5}{|l|}{ Aldehydes } \\
\hline 2-methyl pentanal & 1.6608 & MS, STD & $0.017 \pm 0.01$ & $0.026 \pm 0.02$ \\
\hline 2-methyl propanal & 1.8778 & MS, STD & $0.006 \pm 0.00$ & $0.010 \pm 0.01$ \\
\hline 3-methyl butanal & 2.587 & MS, STD & $0.014 \pm 0.01$ & $0.017 \pm 0.01$ \\
\hline 2-methyl butanal & 2.699 & MS, STD & $0.014 \pm 0.01$ & $0.016 \pm 0.01$ \\
\hline Pentanal & 3.154 & MS, STD & $0.076 \pm 0.03$ & $0.134 \pm 0.12$ \\
\hline Heptanal & 8.9842 & MS, STD & $0.090 \pm 0.05$ & $0.148 \pm 0.09$ \\
\hline Hexanal & 5.8122 & MS, STD & $1.440 \pm 0.62^{b}$ & $2.666 \pm 1.82^{a}$ \\
\hline Benzaldehyde & 10.541 & MS, STD & $0.156 \pm 0.19$ & $0.181 \pm 0.16$ \\
\hline Octanal & 11.6266 & MS, STD & $0.135 \pm 0.05^{b}$ & $0.194 \pm 0.17^{a}$ \\
\hline Nonanal & 13.8771 & MS, STD & $0.071 \pm 0.03$ & $0.107 \pm 0.05$ \\
\hline E,2-nonenal & 14.9997 & MS, STD & $0.030 \pm 0.02$ & $0.021 \pm 0.01$ \\
\hline Benzeneacetaldehyde & 12.5696 & MS, STD & $0.007 \pm 0.00$ & $0.008 \pm 0.00$ \\
\hline E,2-Octenal & 12.8868 & MS, STD & $0.005 \pm 0.00$ & $0.010 \pm 0.01$ \\
\hline Decanal & 15.8893 & MS, STD & $0.019 \pm 0.02$ & $0.079 \pm 0.08$ \\
\hline E,2-decenal & 16.9166 & MS, STD & $0.015 \pm 0.00^{b}$ & $0.023 \pm 0.01^{\mathrm{a}}$ \\
\hline Undecenal & 17.721 & MS, STD & nd & $0.004 \pm 0.00$ \\
\hline 2-undecenal & 18.69 & MS, STD & $0.003 \pm 0.00$ & $0.003 \pm 0.00$ \\
\hline \multicolumn{5}{|l|}{ Alcohols } \\
\hline 2-Heptanol & 3.615 & MS, STD & $0.008 \pm 0.01$ & $0.011 \pm 0.02$ \\
\hline 1-Pentanol & 4.7849 & MS, STD & $0.041 \pm 0.02$ & $0.082 \pm 0.06$ \\
\hline Hexanol & 5.526 & MS, STD & $0.004 \pm 0.00$ & $0.008 \pm 0.01$ \\
\hline 1-Hexanol & 8.0362 & MS, STD & $0.019 \pm 0.01$ & $0.025 \pm 0.02$ \\
\hline 1-Heptanol & 10.827 & MS, STD & $0.033 \pm 0.03$ & $0.053 \pm 0.05$ \\
\hline 1-Octen-3-ol & 11.097 & MS, STD & $0.017 \pm 0.01^{b}$ & $0.043 \pm 0.03^{\mathrm{a}}$ \\
\hline 1-Octanol & 13.1569 & MS, STD & $0.004 \pm 0.00$ & $0.007 \pm 0.01$ \\
\hline \multicolumn{5}{|c|}{ Sulfur- and nitrogen-containing compounds } \\
\hline Methanethiol & 1.5234 & MS, STD & $0.003 \pm 0.00$ & $0.004 \pm 0.00$ \\
\hline Carbon disulfide & 1.7352 & MS, STD & $0.003 \pm 0.00$ & $0.005 \pm 0.00$ \\
\hline Methional & 9.0956 & MS, STD & $0.004 \pm 0.00$ & nd \\
\hline Benzothiazole & 16.297 & MS, STD & nd & $0.006 \pm 0.00$ \\
\hline \multicolumn{5}{|l|}{ Pyrazines } \\
\hline Methylpyrazine & 6.554 & MS, STD & $0.014 \pm 0.02$ & $0.015 \pm 0.02$ \\
\hline 2,5-dimethylpyrazine & 9.1856 & MS, STD & $0.026 \pm 0.01$ & $0.037 \pm 0.03$ \\
\hline 2,3-dimethylpyrazine & 9.4184 & MS & $0.029 \pm 0.00$ & $0.009 \pm 0.01$ \\
\hline 3-Ethyl-2,5-dimethylpyrazine & 13.3741 & MS & $0.008 \pm 0.00$ & $0.013 \pm 0.01$ \\
\hline 2-ethyl-3,5-dimethyl pyrazine & 13.4569 & MS & $0.003 \pm 0.00$ & nd \\
\hline \multicolumn{5}{|l|}{ Hydrocarbons } \\
\hline Toluene & 4.7161 & MS, STD & $0.004 \pm 0.00$ & $0.006 \pm 0.00$ \\
\hline Ethylbenzene & 7.7503 & MS, STD & $0.003 \pm 0.00$ & $0.006 \pm 0.00$ \\
\hline 1,3-dimethylbenzene & 7.9939 & MS, STD & $0.026 \pm 0.02$ & $0.044 \pm 0.03$ \\
\hline 2(5H)-Furanone & 9.365 & MS & $0.026 \pm 0.01$ & $0.028 \pm 0.03$ \\
\hline 5-ethyl-2-methyloctane & 12.3414 & MS & $0.009 \pm 0.01$ & $0.011 \pm 0.01$ \\
\hline 2,6-dimethyloctane & 12.7915 & MS & $0.008 \pm 0.00$ & $0.011 \pm 0.01$ \\
\hline 2,5,9-trimethyldecane & 13.0034 & MS & $0.005 \pm 0.00$ & $0.007 \pm 0.00$ \\
\hline 4,8-dimethyldecane & 13.2628 & MS & $0.008 \pm 0.00$ & $0.007 \pm 0.00$ \\
\hline Octanoic acid & 15.148 & MS, STD & $0.037 \pm 0.03$ & $0.022 \pm 0.01$ \\
\hline Dodecane & 15.7622 & MS, STD & $0.049 \pm 0.01^{b}$ & $0.100 \pm 0.06^{a}$ \\
\hline Anethole & 17.4938 & MS & $0.007 \pm 0.00$ & $0.021 \pm 0.02$ \\
\hline Tetredecane & 19.262 & MS, STD & $0.005 \pm 0.00$ & $0.010 \pm 0.01$ \\
\hline
\end{tabular}

IM, identification method; nd, not detectable.

1) The compounds were identified by mass spectra (MS) from library or external standards (STD).

$a, b$ Means within a same row with different superscripts are significantly different $(p<0.05)$. 
meat) of volatile compounds in the cooked L. lumborum muscles from the two castration groups. In the present study, a total of forty-five volatile compounds including aldehydes (17), alcohols (7), sulfur-and nitrogen-containing compounds (4), pyrazines (5) and hydrocarbons (12) was identified. In the cooked meat samples of both the castration groups, aldehyde was the most predominant class of aroma compounds. Aldehydes associated with fatty and fruity aromas [39], are mainly produced in cooked meat from the oxidation/degradation of fatty acids, and some from the Strecker degradation of amino acids in the Maillard reaction [31]. Out of the aldehydes, 12 compounds were produced from the fatty acids degradation and only four (2-methylpentanal, 2-methylpropanal, 2- and 3-methylbutanal) were produced from the Strecker of amino acids [40]. This indicates that the meat from both castration groups is generally characterized by their high intensity of fatty aroma notes because of increased fat content [31]. The statistical analysis showed that the castration only affected three fatty acids-derived aldehydes (hexanal, octanal and E,2-decenal) whose amounts were higher in the HC group compared to the CC group ( $\mathrm{p}<0.05)$. The higher amount of these long-chain aldehydes (hexanal and E,2-decenal) may be related to the higher level of C18:2n6 content in the HC group (Table 3), since this fatty acid is the main source for generation of the aldehydes during cooking [40]. Out of the alcohols, only 1-octen-3-ol was affected by the castration, with a higher amount found in the HC group $(\mathrm{p}<0.05)$. Furthermore, sulfur-and nitrogen-containing compounds as well as pyrazines associated with meaty and roasted aroma notes are important in the cooked meat flavor [31]. We observed that there were no differences in the amounts of these classes of aroma compounds between two castration groups ( $p>0.05$ ). Overall, the castration method showed a negligible effect on the volatile compounds in the cooked meat, this could be since the half-castration did not cause much change in the flavor precursors such as fatty acids (Table 3) or FAAs (Table 4).

To obtain a trend of the relationship between the castration methods and selected variables, the PCA was carried out. The PCA result (Figure 1) showed that $100 \%$ of the variability was explained by the PC1. The CC group was on the negative PC1 axis; therefore, they were related to the variables such as; total trimming fat (\%), fat content, SFA, glucose, $\mathrm{L}^{*}$ (lightness). Whereas, the $\mathrm{HC}$ was on the positive PC1 axis, therefore, they were related to total meat yield (\%) and meat weight $(\mathrm{kg})$, hexanal, octanal, sweet FAAs, PUFA, and PUFA/SFA etc. This PCA again indicates the differences in the meat yield and some quality traits between the two castration groups. These observations were also similar to the results presented in Table 1 to 5 .

\section{CONCLUSION}

This study for the first time evaluated the effects of castra-

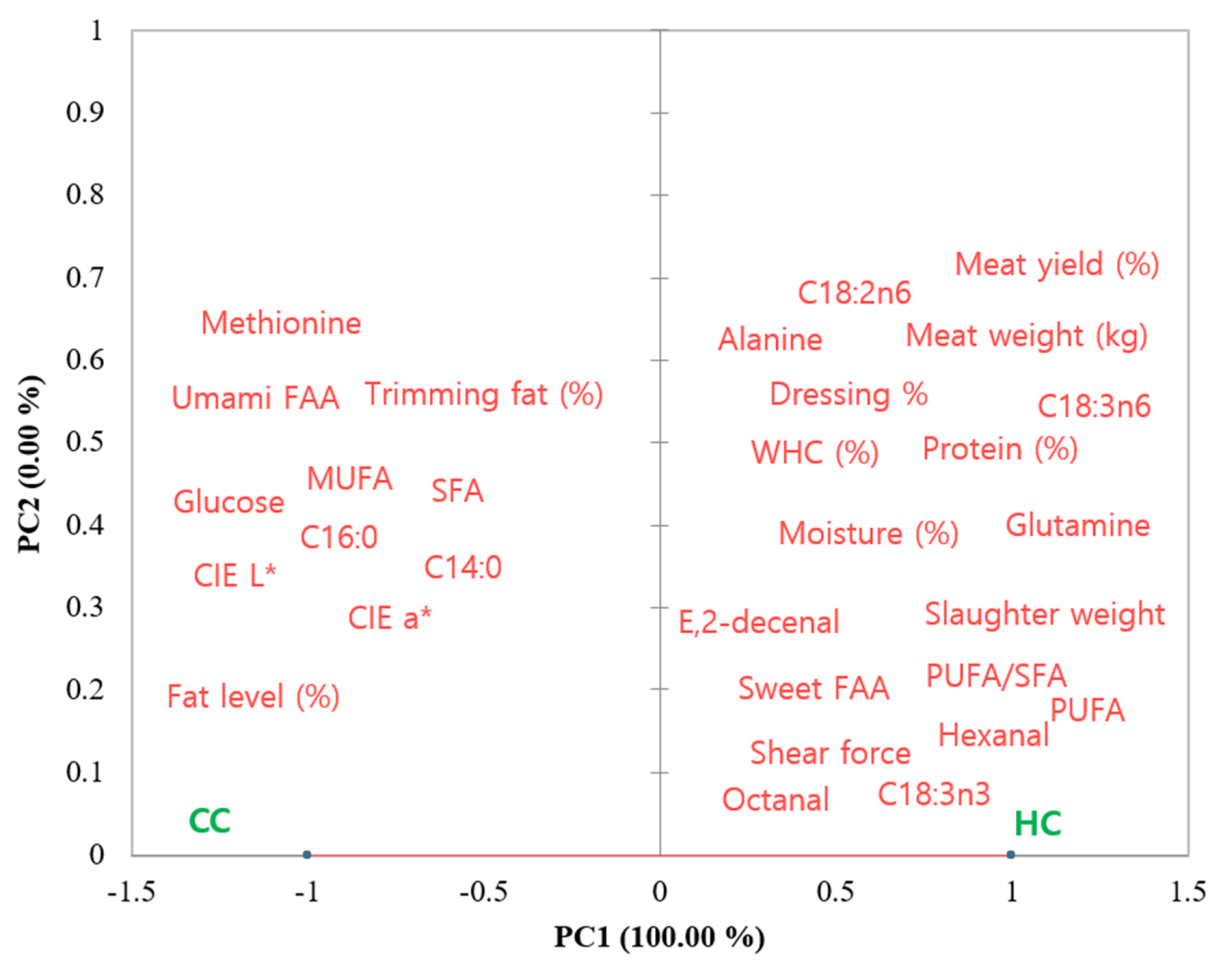

Figure 1. Principal component (PC) analysis for the variables (meat yield and selected quality traits) of meat from the two castration groups. The projection of variables and castration groups (CC, complete-castration; HC, half-castration) in plane defined by the PC1 and PC2. 
tion methods (half-castration and complete castration) on the meat yield and quality characteristics of male cattle. Compared to the complete castration (steers), the half-castration produced more meat yield in almost primal cuts. Compared to the intact males, the fat content in both muscles from the half-castrated animals increased double. More importantly, the half-castration improved the meat tenderness by reducing the shear force values. The half-castration did not affect the MUFAs content, but it increased the total PUFAs content. The total amount of FAAs associated with sweet taste was found to be higher in both muscles from half-castrated animals. Also, the castration method only exhibited a negligible effect on metabolites and volatile aroma compounds in the cooked meat. Based on the results obtained from this study, it may be concluded that the half-castration could be considered as an effective solution to be used for increasing the meat yield and tenderness of male cattle.

\section{CONFLICT OF INTEREST}

We certify that there is no conflict of interest with any financial organization regarding the material discussed in the manuscript.

\section{FUNDING}

This research work was carried out the support of "Cooperative Research Program for Agriculture Science and Technology Development (Project No. PJ014229)" Rural Development Administration, Korea.

\section{REFERENCES}

1. NCBA. Beef industry optimism fueled by strong demand [internet]. 2021 [cited 2021 Mar 1]. Available from: https:// www.drovers.com/news/industry/beef-industry-optimismfueled-strong-demand

2. Castillo MJ, Carpio CE. Demand for high-quality beef attributes in developing countries: The case of Ecuador. J Agric Appl Econ 2019;51:568-90. https://doi.org/10.1017/ aae.2019.21

3. Hobbs JE. Information, incentives and institutions in the agri-food sector. Can J Agric Econ 2003;51:413-29. https:// doi.org/10.1111/j.1744-7976.2003.tb00183.x

4. Lucherk LW, O'Quinn TG, Legako JF, Rathmann RJ, Brooks JC, Miller MF. Consumer and trained panel evaluation of beef strip steaks of varying marbling and enhancement levels cooked to three degrees of doneness. Meat Sci 2016;122: 145-54. https://doi.org/10.1016/j.meatsci.2016.08.005

5. Warner RD, Wheeler TL, Ha M, et al. Meat tenderness: advances in biology, biochemistry, molecular mechanisms and new technologies. Meat Sci 2022;185:108657. https:// doi.org/10.1016/j.meatsci.2021.108657

6. Stewart SM, Lauridsen T, Toft H, et al. Objective grading of eye muscle area, intramuscular fat and marbling in Australian beef and lamb. Meat Sci 2021;181:108358. https://doi.org/10. 1016/j.meatsci.2020.108358

7. Ngapo TM, Brana-Varela D, Rubio-Lozano MS. Mexican consumers at the point of meat purchase. Beef choice. Meat Sci 2017;134:34-43. https://doi.org/10.1016/j.meatsci.2017. 07.013

8. Bretschneider G. Effects of age and method of castration on performance and stress response of beef male cattle: a review. Livest Prod Sci 2005;97:89-100. https://doi.org/10.1016/j. livprodsci.2005.04.006

9. Mach N, Bach A, Realini CE, Font-Furnols M, Velarde A, Devant M. Burdizzo pre-pubertal castration effects on performance, behaviour, carcass characteristics, and meat quality of Holstein bulls fed high-concentrate diets. Meat Sci 2009; 81:329-34. https://doi.org/10.1016/j.meatsci.2008.08.007

10. Marti S, Realini CE, Bach A, Perez-Juan M, Devant M. Effect of castration and slaughter age on performance, carcass, and meat quality traits of Holstein calves fed a high-concentrate diet. J Anim Sci 2013;91:1129-40. https://doi.org/10.2527/ jas.2012-5717

11. Prado IN, Campo MM, Muela E, et al. Effects of castration age, dietary protein level and lysine/methionine ratio on animal performance, carcass and meat quality of Friesian steers intensively reared. Animals 2014;8:1561-8. https://doi. org/10.1017/S1751731114001591

12. Steen RWJ. The effect of plane of nutrition and slaughter weight on growth and food efficiency in bulls, steers and heifers of three breed crosses. Livest Prod Sci 1995;42:1-11. https://doi.org/10.1016/0301-6226(95)00002-3

13. Knight TW, Cosgrove GP, Lambert MG, Death AF. Effects of method and age at castration on growth rate and meat quality of bulls. New Zealand J Agric Res 1999;42:255-68.

14. Aricett JA, Rotta PP, Prado RM, et al. Carcass characteristics, chemical composition and fatty acid profile of longissimus muscle of bulls and steers finished in a pasture system bulls and steers finished in pasture systems. Asian-Australas J Anim Sci 2008;21:1441-8. https://doi.org/10.5713/ajas.2008.80061

15. Korea Institute for Animal Products Quality Evaluation. Animal Products Grading Statistical Yearbook, 5th ed. Sejong, Korea: Korea Institute for Animal Products Quality Evaluation; 2021. No. 11-b552679-000006-12.

16. Singh R, Artaza JN, Taylor WE, Gonzalez-Cadavid NF, Bhasin $\mathrm{S}$. Androgens stimulate myogenic differentiation and inhibit adipogenesis in $\mathrm{C} 3 \mathrm{H} \mathrm{10T1/2}$ pluripotent cells through an androgen receptor-mediated pathway. Endocrinology 2003; 144:5081-8. https://doi.org/10.1210/en.2003-0741

17. Ahn JS, Kwon EG, Lee HJ, et al. Effect of Hemi-castration on the productivity, histological characteristics, and economic efficacy of Korean beef cattle. Animals 2021;11:2490. https:// 
doi.org/10.3390/ani11092490

18. Korean Hanwoo beef Cutting Specification. Wanju-gun, Korea: National Institute of Animal Science, Rural Development Administration; 2018. pp. 11-43.

19. Hoa VB, Seong PN, Cho SH, et al. Quality characteristics and flavor compounds of pork meat as a function of carcass quality grade. Asian-Australas J Anim Sci 2019;32:1448-57. https://doi.org/10.5713/ajas.18.0965

20. Cho SH, Seol KH, Kang SM, et al. Comparison of tastes-related components and eating quality between Hanwoo steer and cow longissimus thoracis muscles. Food Sci Anim Resour 2020;40:908- 23. https://doi.org/10.5851/kosfa.2020.e58

21. Hoa VB, Ryu KS, Hwang IH. Flavor characteristics of Hanwoo beef in comparison with other Korean foods. Asian-Australas J Anim Sci 2012;25:435-46. https://doi.org/10.5713/ajas.2011. 11286

22. Marti S, Jackson JA, Slootmans N, et al. Effects on performance and meat quality of Holstein bulls fed high concentrate diets without implants following immunological castration. Meat Sci 2017;126:36-42. https://doi.org/10.1016/j.meatsci. 2016.11.013

23. Traish AM, Haider A, Doros G, Saad F. Long-term testosterone therapy in hypogonadal men ameliorates elements of the metabolic syndrome: an observational, long-term registry study. Int J Clin Pract 2014;68:314-29. https://doi. org/10.1111/ijcp.12319

24. Blouin K, Nadeau M, Perreault M, et al. Effects of androgens on adipocyte differentiation and adipose tissue explant metabolism in men and women. Clin Endocrinol 2010;72:17688. https://doi.org/10.1111/j.1365-2265.2009.03645.x

25. das Gracas Padre R, Aricett JA, Moreira FB, et al. Fatty acid profile, and chemical composition of Longissimus muscle of bovine steers and bulls finished in pasture system. Meat Sci 2006;74:242-8. https://doi.org/10.1016/j.meatsci.2006. 02.012

26. Hughes JM, Oiseth SK, Purslow PP, Warner RD. A structural approach to understanding the interactions between colour, water-holding capacity and tenderness. Meat Sci 2014;98: 520-32. https://doi.org/10.1016/j.meatsci.2014.05.022

27. Belew JB, Brooks JC, McKenna DR, Savell JW. WarnerBratzler shear evaluations of 40 bovine muscles. Meat Sci 2003;64:507-12. https://doi.org/10.1016/S0309-1740(02)00 242-5

28. Boleman SJ, Boleman SL, Miller RK, et al. Consumer evaluation of beef of known categories of tenderness. J Anim Sci 1997;75:1521-4.

29. Destefanis G, Brugiapaglia A, Barge MT, Lazzaroni C. Effect of castration on meat quality in Piemontese cattle. Meat Sci 2003;64:215-8. https://doi.org/10.1016/s0309-1740(02)00 184-5

30. Amatayakul-Chantler S, Hoe F, Jackson JA, et al. Effects on performance and carcass and meat quality attributes following immunocastration with the gonadotropin releasing factor vaccine Bopriva or surgical castration of Bos indicus bulls raised on pasture in Brazil. Meat Sci 2013;95:78-84. https:// doi.org/10.1016/j.meatsci.2013.04.008

31. Mottram DS. Flavor formation in meat and meat products: a review. Food Chem 1998;62:415-24. https://doi.org/10. 1016/S0308-8146(98)00076-4

32. American Heart Association. Heart and stroke encyclopedia: Dietary guidelines for healthy American adults. Cholesterol. Fat [internet] 2008 [cited 2021 Nov 20]. Available from: http://www.americanheart.org

33. Lee JY, Oh DY, Kim HJ, Jang GS, Lee SU. Detection of superior genotype of fatty acid synthase in Korean native cattle by an environment-adjusted statistical model. Asian-Australas J Anim Sci 2017;30:765-72. https://doi.org/10.5713/ajas.16.0263

34. Takahashi H, Rikimaru K, Kiyohara R, Yamaguchi S. Effect of Arachidonic acid-enriched oil diet supplementation on the taste of broiler meat. Asian-Austrlas J Anim Sci 2012;25: 845-51. https://doi.org/10.5713/ajas.2011.11517

35. Sasaki K, Motoyama M, Mitsumoto M. Changes in the amounts of water-soluble umami-related substances in porcine longissimus and biceps femoris muscles during moist heat cooking. Meat Sci 2007;77:167-72. https:/doi.org/10.1016/ j.meatsci.2007.02.025

36. Ramalingam V, Song Z, Hwang I. The potential role of secondary metabolites in modulating the flavor and taste of the meat. Food Res Int 2019;122:174-82. https://doi.org/10. 1016/j.foodres.2019.04.007

37. Frank D, Hughes J, Piyasiri U, et al. Volatile and non-volatile metabolite changes in 140-day stored vacuum packaged chilled beef and potential shelf life markers. Meat Sci 2020; 161:108016. https://doi.org/10.1016/j.meatsci.2019.108016

38. Jayasena DD, Ahn DU, Nam KC, Jo C. Flavour chemistry of chicken meat: a review. Asian-Australas J Anim Sci 2013;26: 732-42. https://doi.org/10.5713/ajas.2012.12619

39. Aaslyng MD, Meinert L. Meat flavour in pork and beef From animal to meal. Meat Sci 2017;132:112-7. https://doi. org/10.1016/j.meatsci.2017.04.012

40. Hoa VB, Amna T, Hwang IH. Significant influence of particular unsaturated fatty acids and $\mathrm{pH}$ on the volatile compounds in meat-like model systems. Meat Sci 2013;94:4808. https://doi.org/10.1016/j.meatsci.2013.04.029 